\title{
OSMOTIC DEHYDRATION OF APPLES UNDER REDUCED PRESSURE CONDITIONS
}

\author{
Siemowit Muszyński ${ }^{*}$ Krzysztof Kornarzyński, Bożena Gładyszewska \\ Department of Physics, University of Life Sciences in Lublin \\ *Corresponding author: e-mail: siemowit.muszynski@up.lublin.pl
}

\begin{tabular}{l}
\hline ARTICLE INFO \\
\hline Article history: \\
Received: January 2016 \\
Received in the revised form: \\
March 2016 \\
Accepted: April 2016 \\
\hline Key words: \\
osmotic dehydration, \\
reduced pressure, \\
fruit, \\
apple, \\
sucrose
\end{tabular}

ABSTRACT
The aim of the study was to determine the effect of reduced pressure
on the osmotic dehydration of apples. Tests were performed under
vacuum of $8 \mathrm{kPa}, 67 \mathrm{kPa}, 80 \mathrm{kPa}$ and under the atmospheric pressure
( $100 \mathrm{kPa})$. The samples were dehydrated in a sucrose solution with
a concentration of $30^{\circ} \mathrm{Bx}, 50^{\circ} \mathrm{Bx}$ and $70^{\circ} \mathrm{Bx}$. It has been shown that the
effect of low pressure application depends significantly to the concen-
tration of the osmotic solution. It has been found that the overall
weight change significantly depend on the concentration of the solu-
tion, and after 3 hours of dehydration at a pressure of $80 \mathrm{kPa}$ at solu-
tions of $30^{\circ} \mathrm{Bx}, 50^{\circ} \mathrm{Bx}$ and $70^{\circ} \mathrm{Bx}$ total weight loss increased by
$65 \%, 12 \%$ and $25 \%$ respectively, when compared to samples dehydrat-
ed at atmospheric pressure. From the studied variants of reduced
pressure, the pressure of $80 \mathrm{kPa}$ seems to be the optimal one, as evi-
denced by the lowest values of weight gain to water loss ratios for
apples dehydrated in solutions of $50^{\circ} \mathrm{Bx}$ and $70^{\circ} \mathrm{Bx}$.

\section{Introduction and objective of the research}

Osmotic dehydration is a commonly used method which aims at partial removal of water from food in order to obtain a product with a lower content thereof as one of the production stages of food from plant raw material (Soliva-Fortuny and Belloso, 2003; Grzegory et al., 2013). It enables obtaining low-processed food rich in natural nutrients and if it is needed - saturated with additional substances with an increased nutritious value, as a result of which initially processed fruit may be subjected to further preservation.

Osmotic dehydration consists in immersing fruit in hypertonic osmotic solutions as a result of which water is removed from tissue and solution components are introduced. Because membranes, through which osmotic transport is carried out, are not selective, water diffusion is accompanied also by transport of other solved substances from the inside of the material to the solution. Thus, the quality of the obtained product depends not only on the property of the processed fruit (structural and textural properties, geometry of the sample, initial water, sugar and acids content, composition and concentration of the used hypertonic solution) but also on the selection of appropriate physical conditions in which osmotic dehydration is carried out. In this aspect, conditions during dehydration - temperature and pressure are decisive. Numerous experiments proved that there is a positive correlation 
between temperature and dehydration kinetics (Barat et al., 2001; Jałoszyński et al., 2013; Pasławska et al., 2013, Surma et al., 2013).

However, the increase of temperature influences the physico-chemical properties of the obtained products causing the losses of nutrients, change in the structure, destruction of cell membranes, the loss of their semi-permissive properties and the increase of the osmotic substance content penetrating inside (Lewicki et al., 1998). The osmotic process disturbs the cell structure of tissue and leads to cell deformation especially in the surface layer. Additional thermal processing may lead to more extensive destruction of the initial cell structure in tissues.

Osmotic dehydration carried out in the conditions of reduced pressure is called vacuum dehydration. It is a method which enables better use of porous structure of the dehydrated food (Fito and Rastor, 1994). An advantage of vacuum dehydration is the fact that as a result of degassing of the solution and dehydrated sample, an active surface of impact between the solution and dehydrated material increases because degassed surface pores and micro-tunnels in the material structure also can fill with osmotic solution. Since the active surface between the fruit-solution phases, through which exchange takes place, weight is increased, dehydration in the conditions of reduced pressure has a greater rate of kinetics than in atmospheric conditions. A relevant combination of pressure and solution concentration enables higher control of osmoactive factor penetration to the inside of the dehydrated product, which not only decreases the degree of cell damage but also in consequence a product with lower sugar content is obtained than during dehydration carried out in the conditions of normal pressure (Martinez-Monzo et al., 1998).

It should be also noted that each fruit has a specific content of water, sugar, acids and has a different susceptibility to technological treatments and has individual mechanical properties, structure and firmness of pulp. These properties influence the rate of reduction of water content, degree of penetration of osmotic substance and the change of mechanical properties and chemical composition during dehydration (Shi et al., 1995; Mujica-Paz et al., 2003).

The objective of the paper was to determine the impact of the reduced pressure on the course of osmotic dehydration of apples. The scope of the paper included the analysis of content changes, water loss and the increase of dry substance during osmotic dehydration in the sucrose solution with varied concentration. For research of the impact of reduced pressure on the course of dehydration, apples were selected because their structure is considerably porous and thus the impact of the reduced pressure should be particularly visible.

\section{Materials and methods}

Ligol apples purchased in the local fruit market were used for the research. Raw material in the form of whole apples, to the moment experiments were carried out, was stored in the cooling conditions $\left(5^{\circ} \mathrm{C}\right)$ by the period no longer than 14 days. Three hours before the experiment apples were taken out of the fridge and placed in the room conditions (20$25^{\circ} \mathrm{C}$ ). With stainless steel knife and cutter pulp cubes with dimensions of $10 \times 10 \times 12 \mathrm{~mm}$ were cut out from apples. Samples with the total weight of cubes of approx. $20 \mathrm{~g}$ were placed in beakers with the volume of $200 \mathrm{ml}$ and were covered with $100 \mathrm{ml}$ of the solution with sucrose content of $30^{\circ} \mathrm{Bx}, 50^{\circ} \mathrm{Bx}$ or $70^{\circ} \mathrm{Bx}$, thus the weight relation of raw material to 
Osmotic dehydration...

the osmotic solution was 1:5. Solutions were made the same day with the basis of distilled water and pure sucrose. In order to secure apples against floating on the surface of the solution they were loaded with a stainless steel net. Osmotic dehydration was carried out in static conditions without mixing.

Beakers with samples were placed inside a cylindrical vacuum chamber with the internal diameter $20 \mathrm{~cm}$ and the height of $13 \mathrm{~cm}$. The chamber was made of acid-proof steel except for the cover made of acrylic glass $1 \mathrm{~cm}$ thick which was sealed to the chamber with a gum sealer smeared with technical silicone.

Dehydration tests were carried out under atmospheric pressure of $100 \mathrm{kPa}$ and in the vacuum conditions at the pressure of $80 \mathrm{kPa}, 67 \mathrm{kPa}$ and $8 \mathrm{kPa}$. Air from the chamber was removed with a vacuum pump (BL-60, Tepra, Koszalin), pressure was measured with a vacuum measuring device VEB (Hochvacuum, Dresden) equipped with an option of electronic and hand read-out, The time after which the desired under pressure was obtained was approx. 2 minutes. Dehydration at the set pressure was carried out within 180 minutes in the temperature of $25^{\circ} \mathrm{C}$. Inside the chamber there was a thermocouple placed (Lutron TM-906A) which registers the temperature changes with a precision to $\pm 0.1^{\circ} \mathrm{C}$. Pressure in the chamber was obtained with maintenance of isothermal conditions, i.e. which do not cause temperature changes inside the chamber by more than $\pm 2^{\circ} \mathrm{C}$. After the set dehydration time, the pressure inside the chamber increased in time by approx. 2 minutes to the moment of obtaining the value of atmospheric pressure. Dehydrated apples were washed out with distilled water by approx. 30 seconds and then placed for approx. 60 seconds of filter papers to remove water excess from the surface of samples.

During each experiment the weight of samples before and after the dehydration process and the content of dry substance were determined with a gravimetric method by heating in a chamber drier with a natural air circulation in the temperature of $70^{\circ} \mathrm{C}$ for 48 hours (Polish Norm PN-A-75101-03, 1990).

The following parameters were used for description of kinetics of the processes which occur in dehydrated apples: water loss (WL), change of the dry mass content (SG), total weight change (MG) and the relation of the weight gain to water loss (SWR), which were calculated based on the balance of weight change in comparison to fresh samples weight (wet basis - w.b.) based on the following relations (Fito and Pastor, 1994; Fito, 2004):

$$
\begin{gathered}
W L=\frac{M_{F} W_{F}-M_{0} W_{0}}{M_{0}}\left(\mathrm{~kg} \cdot \mathrm{kg}_{\text {w.b. }}{ }^{-1}\right) \\
S G=\frac{M_{F}\left(1-W_{F}\right)-M_{0}\left(1-W_{0}\right)}{M_{0}}\left(\mathrm{~kg} \cdot \mathrm{kg}_{\text {w.b. }}{ }^{-1}\right) \\
M G=\frac{M_{F}-M_{0}}{M_{0}}\left(\mathrm{~kg} \cdot \mathrm{kg}_{\text {w.b. }}{ }^{-1}\right) \\
S W R=\frac{S G}{W L}(-)
\end{gathered}
$$


where:

$\mathrm{M}_{0}$ - initial weight of a sample, $(\mathrm{kg})$

$\mathrm{M}_{\mathrm{F}}$ - sample weight after dehydration, $(\mathrm{kg})$

$\mathrm{W}_{0}$ - initial content of water in a sample, $\left(\mathrm{kg} \cdot \mathrm{kg}_{\mathrm{w} . \mathrm{b} .}{ }^{-1}\right)$

$\mathrm{W}_{\mathrm{F}}-$ water content after dehydration, $\left(\mathrm{kg} \cdot \mathrm{kg}_{\mathrm{w} . \mathrm{b}^{-1}}{ }^{-1}\right)$

All measurements were carried out in 3 replications and the data are presented as mean values \pm standard deviation. Statistical analysis of the obtained results was carried out with the use of SigmaStat program based on a single-factor analysis of variance ANOVA followed with in the Tukey's test by multiple mutwat comparison (all-parwise) of all samples. A p-value less than 0.05 was considered statistically significant.

\section{Results of research and their analysis}

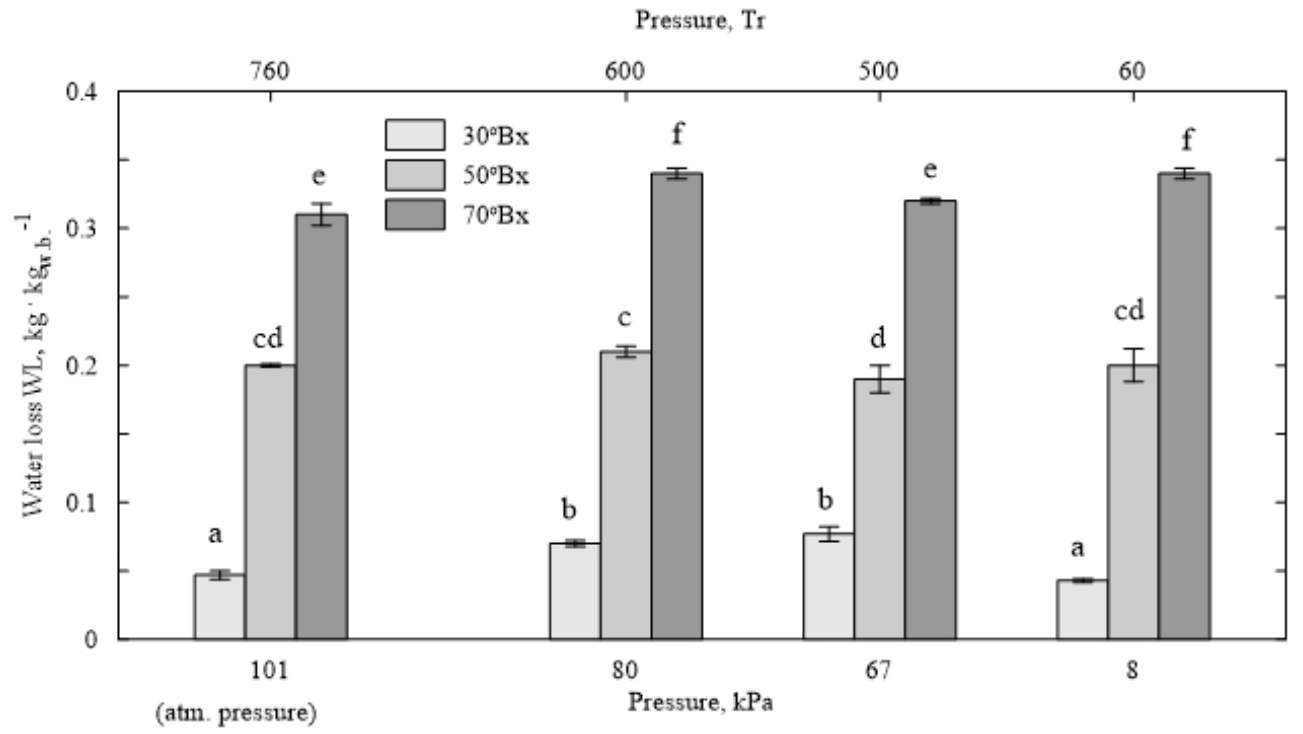

Figure 1. Effect of pressure on apples water loss WL osmotically dehydrated in different concentration of osmotic solution

Water loss in apples depended significantly on the concentration of osmotic solution and less on the applied pressure (fig. 1). Reduction of pressure did not affect obtaining statistically significant difference in water loss in raw material dehydrated in the solution with concentration of $50^{\circ} \mathrm{Bx}$, in comparison to the sample dehydrated under normal conditions. For samples dehydrated in the solution of $30^{\circ} \mathrm{Bx}$ statistically significant water loss took place only in case of reduced pressure of $67 \mathrm{kPa}$ and $80 \mathrm{kPa}$ at the highest concentration of osmotic solution, increase of water loss took place in case of pressures of $8 \mathrm{kPa}$ and $80 \mathrm{kPa}$ but it was comparable in both cases. 


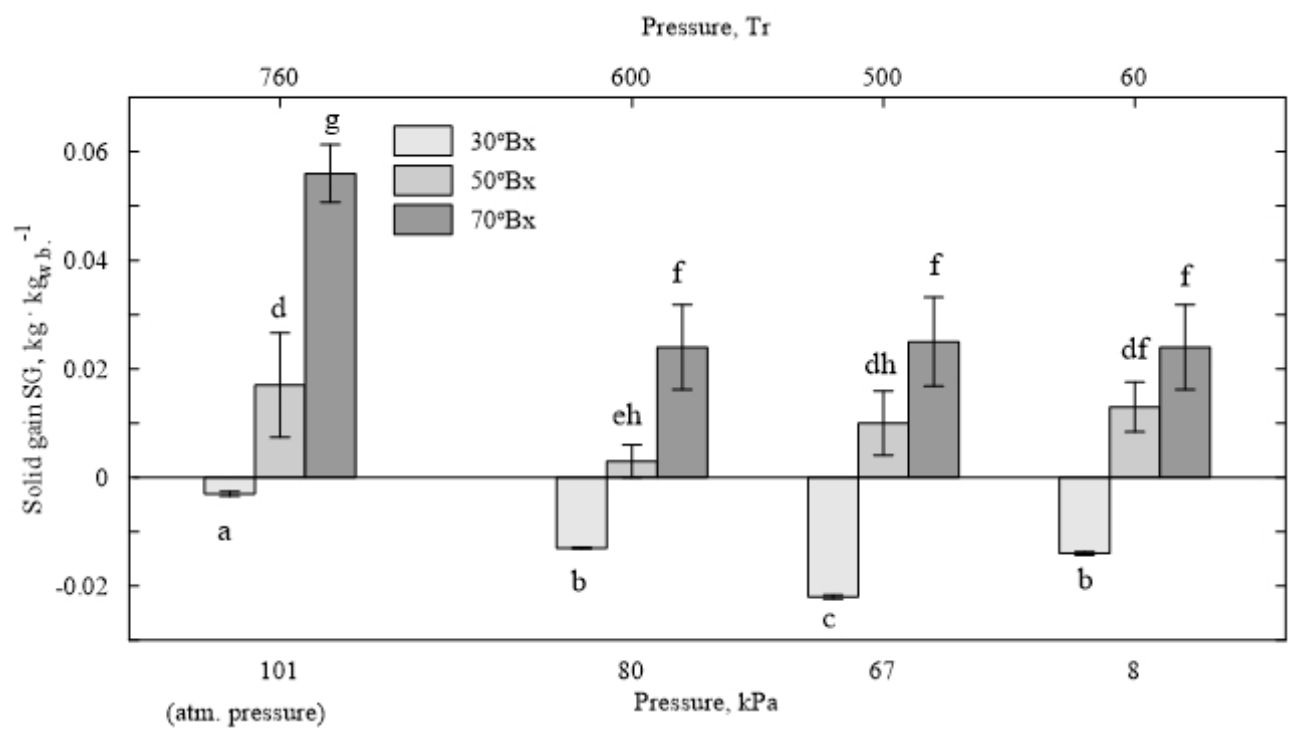

Figure 2. Effect of pressure on apples solid gain SG osmotically dehydrated in different osmotic solutions

Similarly, as reduction of pressure significantly influenced the increase of water content loss WL in four of twelve investigated combinations of pressure and solution concentration, in a statistically significant manner it influenced the reduction of dry mass SG gain for as much as seven investigated samples (fig.2). Reduction of pressure did not affect the water loss WL from apples dehydrated in the solution with concentration of $50^{\circ} \mathrm{Bx}$ (fig. 1) but the increase of dry mass SG for pressure $80 \mathrm{kPa}$ was considerably lower. For the remaining pressures SG increase was only insignificant and statistically insignificant, lower than in case of atmospheric pressure. At the same time it was found that reduction of pressure caused in all cases reduction of the increase of dry substance of apples dehydrated in the solution of $70^{\circ} \mathrm{Bx}$. They were characterized with almost twofold decrease of SG increase in comparison to experiments carried out in normal conditions. During dehydration in the solution with concentration of $30^{\circ} \mathrm{Bx}$ in all cases also in the control group SG loss took place, namely the amount of substance which got to the solution was higher than the amount of the absorbed sugar.

The use of vacuum influenced the intensification of mass exchange between the dehydrated apples and the surrounding immersion solution. Mechanism responsible for this effect may be following: after pumping off part of air, a pressure gradient was formed which resulted in the sudden outflow from the part of gases from the inside of a sample and the remaining gases increased their volume and filled in empty places, as a result of which osmoactive substance penetrated the inside of the sample slower. Since, the reduced pressure was maintained by entire time, there was no compression of remaining gases, which could cause additional penetration of sucrose solution to the inside of the sample. This effect could have been formed due to the increase of the surface of the solution-sample 
contact and washing out the substance to the solution (Rahman, 2001; Grzegory et al., 2013; Wang et al., 2015).

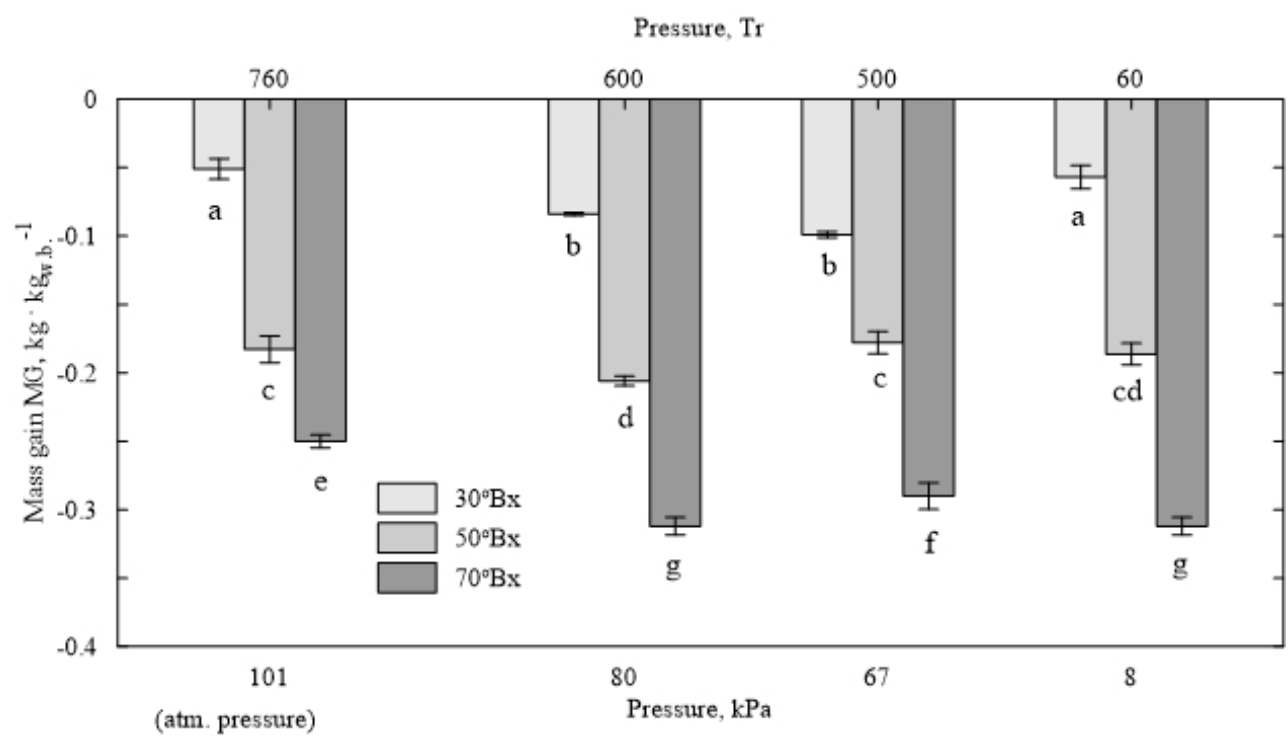

Figure 3. Effect of pressure on apples total mass gain MG osmotically dehydrated in different solutions

As a result of a bigger water loss in comparison to the gain (or in case of solution $30^{\circ} \mathrm{Bx}$ - loss) of dry substance of processed apples, their mass MG decreased (fig. 3). The magnitude of changes depends both on the sucrose concentration as well as on the applied pressure. The increase of apple mass losses along with the increase of concentration of the used solution was determined. Reduction of pressure caused significant increase of total mass loss of samples dehydrated in the solution with low $\left(30^{\circ} \mathrm{Bx}\right)$ and high $\left(70^{\circ} \mathrm{Bx}\right)$ sucrose concentration. Comparing water losses (fig.1) and the dry substance gain (fig. 5) one may state that it is related mainly to lower increase of dry substance which combines both penetration of sugar and washing out to the solution of soluble substances from the-inside of apples.

In case of a solution of concentration of $30^{\circ} \mathrm{Bx}$, the increase of the total exchange of mass was observed for both pressure of $80 \mathrm{kPa}$, as well as for $67 \mathrm{kPa}$, where almost twofold exchange of mass in comparison to the control sample was reported. In case of $70^{\circ} \mathrm{Bx}$ solution these changes were statistically significant for all used vacuum conditions. Absolute mass losses in comparison to the mass of fresh samples in the conditions of the reduced pressure exceeded $30 \%$, towards the loss by $25 \%$ of the observed during dehydration under atmospheric pressure. During dehydration in the $50^{\circ} \mathrm{Bx}$ solution, a statistically significant total mass change in comparison to samples dehydrated under atmospheric pressure was reported only when dehydration took place pressure of $80 \mathrm{kPa}$, when absolute mass change in comparison to fresh apples exceeded $20 \%$. 


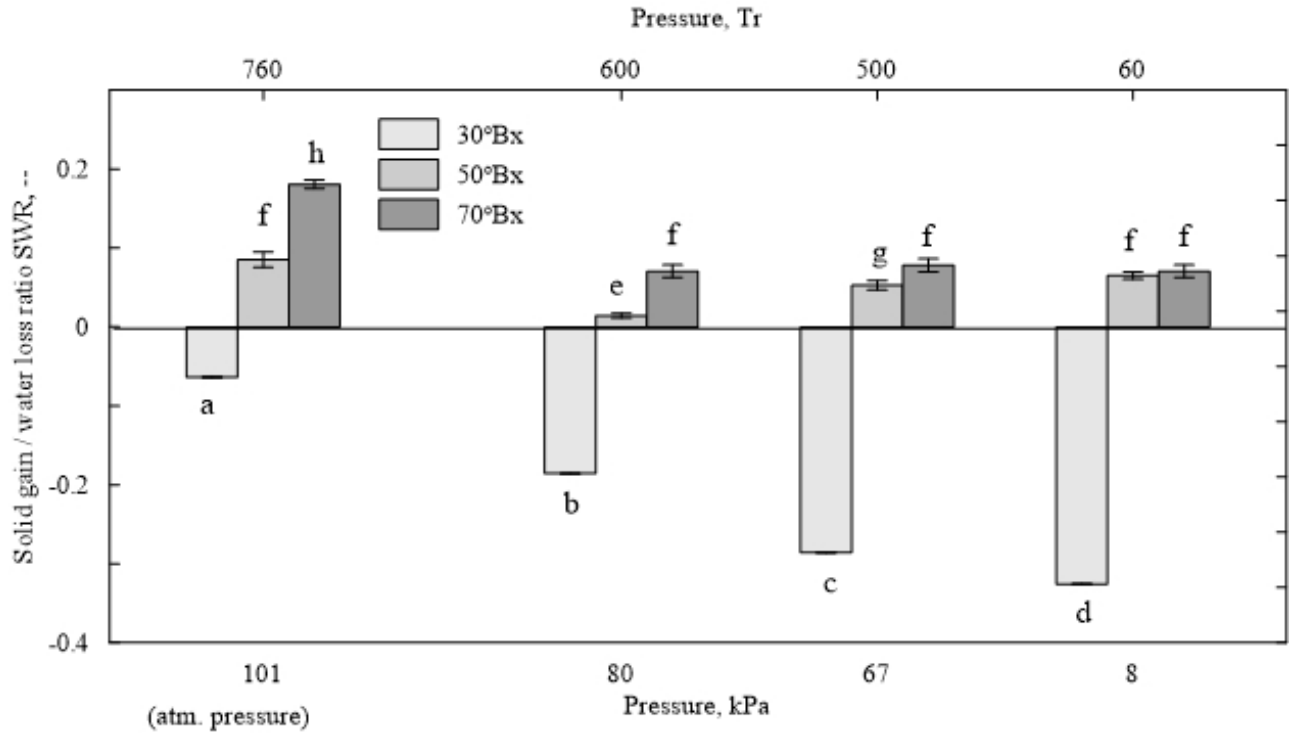

Figure. 4. Effect of pressure on apples solid gain to water loss ratio SWR of apples osmotically dehydrated in different solutions

Fig. 4 presents the relation of the mass gain to water loss SWR which is an indicator of dehydration process efficiency. Generally, lower SWR values indicate an optimal relation of water loss at the simultaneous limited penetration of sugar also in case of dehydration under reduced pressure (Wang et al., 2015). In case of high $\left(70^{\circ} \mathrm{Bx}\right)$ concentration of sucrose pressure reduction in all cases led to obtaining a uniform, almost twofold, reduction of SWR value. For $50^{\circ} \mathrm{Bx}$ concentration, reduction of pressure to the value of $80 \mathrm{kPa}$ influenced obtaining the lowest and thus the best value of the relation of water loss to the gain of dry substance in comparison to all other experiments. In case of $30^{\circ} \mathrm{Bx}$ concentration each reduction of pressure led to a statistically significant increase of SWR value. It is known that it resulted from the increase of dry mass SG loss. Therefore, in case of low concentrations of sucrose one may say that the use of vacuum leads to worsening of the quality of the product obtained in consequence of osmotic dehydration. Howerver, this result may also be a consequence of long duration of the experiment (180 minutes). In case of osmotic dehydration of apples it was proved that dehydration lasting longer than 120 minutes leads to disintegration of pulp tissues resulting in their tearing apart (Lewicki and Pawlak, 2005; Yadav and Singh, 2012). Probably, shorter time of dehydration would not lead to such a significant loss of dry substance if reduced pressure would have been used. 


\section{Conclusion}

1. When assessing the efficiency of osmotic dehydration in the reduced pressure conditions, concentration of osmotic solution is significant. At all pressures, water losses WL, increase of dry substance SG and total mass change MG of dehydrated apples differed statistically significantly $(p<0.05)$ for various concentrations of osmotic solutions.

2. Reduction of pressure impeded penetration of surface pores and micro-tunnels by osmotic solution which led to slowing down penetration of osmo-active substance penetration to the inside of a sample.

3. In case of concentration of the $30^{\circ} \mathrm{Bx}$ solution, reduction of pressure led clearly to the increase of the negative value of SWR which resulted from the reduction of dry mass content in dehydrated apples. It could have been related to too long time of dehydration, which led to breaking integrity of pulp tissues.

4. If the objective of osmotic dehydration is to obtain high water loss then even reduction of pressure to $80 \mathrm{kPa}$ will enable increase of dehydration efficiency in case of low and high concentration of sucrose.

5. If the objective is to obtain a product with high sugar content as it is in case of succades, reduction of pressure is recommended because as a result thereof usually an explicit $(\mathrm{p}<0.05)$ reduction of dry substance gain takes place, especially in case of using high concentration of sucrose.

\section{References}

Barat, J.M., Chiralt, A., Fito, P. (2001). Effect of osmotic solution concentration, temperature and vacuum impregnation pretreatment on osmotic dehydration kinetics of apple slices. Food Science Technology International, 7, 451-456.

Fito, P. (1994). Modelling of vacuum osmotic dehydration of food. Journal of Food Engineering, 22, 1-4.

Fito, P., Pastor, R. (1994). On some non-diffusional mechanism occurring during vacuum osmotic dehydration. Journal of Food Engineering, 21, 513-519.

Grzegory, P., Piotrowski, D., Bargieł, K. (2013). Influence of freezing treatment, osmotic dehydration and storage time on the rehydration of vacuum dried strawberries. Agricultural Engineering, 4(148), 39-47.

Jałoszyński, K., Pasławska, M., Surma, M., Stępień, B. (2013). Suszenie kalarepy metodą mikrofalową w warunkach obniżonego ciśnienia. Agricultural Engineering, 4(147), 91-99.

Lewicki, P.P., Kowalska, H., Lenart, A. (1998). Effect of temperature on mass transfer during osmotic dehydration of plant tissue. Proc. of Industrial Seminar "Industrial application of osmotic dehydration treatments of food”, Bertinoro, Italy, 44-50.

Lewicki, P.P., Pawlak, R.P. (2005). Effect of osmotic dewatering on apple tissue structure. Journal of Food Engineering, 66, 43-50.

Martinez-Monzo, J., Martinez-Navarrete, N., Chiralt, A., Fito, P. (1998). Mechanical and structural changes in apple (var. Granny Smith) due the vacuum impregnation with cryoprotectants. Journal of Food Science, 63, 499-503.

Mujica-Paz, H., Valdez-Fragoso, A., Lopez-Malo, A., Palou, E., Welti-Chanes, J. (2003). Impregnation and osmotic dehydration of dome fruits: effect of vacuum pressure and syrup concentration. Journal of Food Engineering, 57, 305-314.

Pasławska, M., Jałoszyński, K., Stępień, B., Surma, M. (2013). Mikrofalowo-próżniowe odwadnianie drożdży gorzelniczych. Agricultural Engineering, 4(147), 249-258. 
Osmotic dehydration...

Polish Norm PN-A-75101-03. (1990). Przetwory owocowe i warzywne. Przygotowanie próbek $i$ metody badań fizykochemicznych. Oznaczanie zawartości suchej masy metodą wagową. In Polish.

Rahman, M.S. (2001). Toward prediction of porosity in foods during drying: A brief review. Drying Techology, 19, 1-13.

Shi, X.Q., Fito, P., Chiralt, A. (1995). Influence of vacuum treatment on mass transfer during osmotic dehydration of fruits. Food Research International, 22, 445-454.

Soliva-Fortuny, R.C., Belloso, O.M. (2003). New advances in extending the shelf-life of fresh-cut fruits: a review. Trends in Food Science Technology, 14, 341-353.

Surma, M., Jałoszyński, K., Pasławska, M., Stępień, B. (2013). Analiza procesu suszenia papryki czerwonej w złożu fontannowym z nagrzewaniem mikrofalowym. Agricultural Engineering, 4(147), 345-354.

Wang, Z., Wei, T., Zhang M. (2015). Effects of vacuum and normal pressure impregnation on water loss and solid gain of apple (Malus Pumila Mill). Journal of Food Processing and Preservation, 39, 1045-1050.

Yadav, K.A., Singh, S.V. (2012). Osmotic dehydration of fruits and vegetables: A review. Journal of Food Science and Technology, 22, 1-22.

\section{ODWADNIANIE OSMOTYCZNE JABLEK W WARUNKACH OBNIŻONEGO CIŚNIENIA}

Streszczenie. Celem pracy było określenie wpływu obniżonego ciśnienia na przebieg odwadniania osmotycznego jabłek. Badania przeprowadzono przy zastosowaniu ciśnień $8 \mathrm{kPa}, 67 \mathrm{kPa}, 80 \mathrm{kPa}$ oraz ciśnienia atmosferycznego $(100 \mathrm{kPa})$. Próbki odwadniane były w roztworach sacharozy o stężeniu $30^{\circ} \mathrm{Bx}, 50^{\circ} \mathrm{Bx}$ i $70^{\circ} \mathrm{Bx}$. Wykazano, że przy ocenie obniżonego ciśnienia istotne znaczenie ma stężenie zastosowanego roztworu osmotycznego. Stwierdzono, że całkowite zmiany masy w sposób istotny zależały od stężenia roztworu i po 3 godzinach odwadniania pod ciśnieniem $80 \mathrm{kPa}$ w roztworach $30^{\circ} \mathrm{Bx}, 50^{\circ} \mathrm{Bx}$ i $70^{\circ} \mathrm{Bx}$ ubytki te wzrosły odpowiednio o $65 \%, 12 \%$ i $25 \%$ w stosunku do prób odwadnianych w warunkach ciśnienia atmosferycznego. Z przebadanych wariantów zredukowanego ciśnienia, ciśnienie $80 \mathrm{kPa}$ wydaje się być ciśnieniem optymalnym, o czym świadczą również najniższe wartości stosunku przyrostu masy do ubytku wody dla jabłek odwadnianych w roztworach $50^{\circ} \mathrm{Bx}$ i $70^{\circ} \mathrm{Bx}$.

Słowa kluczowe: odwadnianie osmotyczne, zredukowane ciśnienie, owoce, jabłko, sacharoza 